Wiktor Osuch

Agnieszka Dwojak

Instytut Geografii

Uniwersytet Pedagogiczny im. KEN w Krakowie

\title{
Wspieranie przedsiębiorczości przez przeciwdzialanie marginalizacji społeczno-ekonomicznej grup nieprzystosowanych do konkurencji w gospodarce rynkowej jako dążenie do zrównoważonego rozwoju społeczeństwa informacyjnego (na przykładzie mniejszości romskiej)
}

\section{Przedsiębiorczość a rozwój społeczeństwa informacyjnego}

Zgodnie z opiniami wielu ekonomistów i socjologów, przyszłością wysoko rozwiniętego społeczeństwa europejskiego jest przeobrażenie się w społeczeństwo informacyjne, które posiada rozwinięte środki przetwarzania informacji i komunikowania, a środki te są podstawą tworzenia dochodu narodowego i dostarczają źródła utrzymania większości społeczeństwa (Toborowicz 2008). Koniecznym warunkiem rozwoju nowoczesnych środków przetwarzania informacji i komunikacji jest przedsiębiorcza postawa wszystkich przedstawicieli społeczeństwa.

Społeczeństwo informacyjne wywodzi się niejako ze społeczeństwa przedsiębiorczego, dla którego informacja, jej przekazywanie i przetwarzanie, jest podstawą działalności. Rynek wymusza na przedsiębiorcach stałą elastyczność, aktywność i śledzenie wszystkich istotnych informacji, a te najszybciej docierają do nas nowoczesnymi środkami przekazu.

Mówiąc „społeczeństwo informacyjne”, należy jednak myśleć nie tylko o informatyzacji i nowoczesnych technologiach, ale nade wszystko o ludziach. Społeczeństwo jest zbiorem jednostek różnorodnym etnicznie, religijnie, kulturowo, a wreszcie ekonomicznie. Rozwój społeczeństwa należy rozumieć jako rozwój całości. Pogoń za innowacyjnymi produktami jedynie wąskiej grupy najbogatszej ludności prowadzi do pogłębienia dysproporcji ekonomicznych w społeczności i powolnego ograniczenia więzi społecznych. Działania prorozwojowe powinny być zatem kierowane do całego społeczeństwa, aby jednostkom wyróżniającym się, przedsiębiorczym i ambitnym pomagać, nie zapominając o wspieraniu jednostek najsłabszych, by nie doprowadzić do opóźnień w ich rozwoju ekonomiczno-społecznym.

Założenie, że wszystkie jednostki w danym społeczeństwie będą dobrowolnie dążyć do rozwoju, jest oczywiście utopijne i wynika z równie oczywistego faktu różnorodności ludzkich charakterów i motywacji. Zachowania i postawy ludzkie można łatwo oceniać. Niechęć do pracy czy wysoki poziom nieuzasadnionych absencji bez trudu uznamy za przykład niewłaściwego stosunku do pracy i braku przedsiębiorczości. Zdecydowanie trudniej jest, gdy taka postawa nie dotyczy jednostek i nie wynika z charakteru danej osoby, lecz jest typowa dla całej grupy osób, a jednocześnie stanowi element kultury czy tradycji. Tak jest w przypadku Romów, nie tylko w Polsce. „Różnorodność kulturowa wzbogaca społeczeństwa” - to znane od kilku lat stwierdzenie sympatyków integracji europejskiej. Przyjmuje się przy tym jednak za oczywiste, że elementem 
owej kultury nie są zjawiska jawnie sprzeczne z duchem idei europejskiej, np. podporządkowanie kobiety mężczyźnie, negacja demokracji czy unikanie obowiązku szkolnego.

Przedstawiciele mniejszości narodowych i etnicznych w Polsce, na mocy konstytucji oraz wielu aktów prawa międzynarodowego, mają m.in. wolność zachowania obyczajów i tradycji oraz rozwoju własnej kultury, a także prawo do pomocy ze strony państwa polskiego w wielu dziedzinach życia (Mniejszości narodowe i etniczne w Polsce. Podstawowe prawa - informator na stronie internetowej MSWiA).

Pomoc społeczności romskiej i pozostałym mniejszościom etnicznym i narodowym zarówno w Polsce, jak i w innych krajach, jest warunkiem opisanego wcześniej zrównoważonego rozwoju całego społeczeństwa, w wyniku którego nie może dochodzić do marginalizacji żadnej grupy społecznej.

\section{Sytuacja Romów na rynku pracy}

Naród romski, z liczbą społeczeństwa szacowaną na około $8 \mathrm{mln}$, jest największą europejską mniejszością. Mimo że dzieli się na liczne, odległe od siebie terytorialnie grupy o różnych językach, mające ze sobą znikome kontakty, to dzięki wspólnej tradycji zdołał wytworzyć silny związek etniczny. Romowie „od zawsze” mieszkali na obrzeżach innych społeczeństw, z jednej strony wydaleni z granic i okryci pogardą, z drugiej - kojarzeni z takimi pozytywnymi pojęciami, jak „wolność” i „niezależność”. Z punktu widzenia Romów jest to życie w dwóch różnych rzeczywistościach. Żyją wśród swojej społeczności, aby umacniać rodzinne więzi i pielęgnować tradycje. Aby zarobić na utrzymanie, muszą jednak nawiązać kontakt z nieRomami i dopasować się do silniejszej większości (Fridrich 2007).

Romowie są przykładem grupy społecznej, która zdecydowanie nie nadąża za rozwojem ekonomicznym i gospodarczym współczesnego świata. Należy jednak pamiętać, że opisywane w dalszej części artykułu problemy nie dotyczą całej ich populacji. Społeczność romska w Polsce, podobnie jak w innych krajach europejskich, jest zróżnicowana wewnętrznie, poszczególne grupy różnią się od siebie m.in. postrzeganiem zasad i stosunkiem do takich wartości, jak praca (Paszko 2007). Nie wszyscy Romowie są bezradni na rynku pracy. Część z nich prezentuje postawę przedsiębiorczą i skutecznie prowadzi legalną działalność gospodarczą.

Podstawową wartością decydującą o powodzeniu na współczesnym rynku pracy jest wysoki poziom wykształcenia. Edukacja większości dorosłych Romów kończy się jednak na kilku klasach szkoły podstawowej. Towarzyszy temu również dość słaba znajomość języka polskiego. Poziom wykształcenia Romów opisuje raport Romowie - bezrobocie. Elementy opisu położenia społecznego Romów w Polsce w 1999 r., przygotowany przez Stowarzyszenie Romów w Polsce na zlecenie Krajowego Urzędu Pracy. Wynika z niego, że co trzeci badany Rom nie ukończył szkoły podstawowej, a zaledwie $0,8 \%$ populacji ma wykształcenie wyższe (Paszko, Sułkowski, Zawicki 2007).

Nieudolność większości Romów na rynku pracy potwierdza stopa bezrobocia wśród ludności cygańskiej, którą można określić jako przerażającą. Według danych Ministerstwa Spraw Wewnętrznych i Administracji, w połowie województw liczba bezrobotnych przekraczała 90\% Romów (Sprawozdanie z realizacji programu na rzecz społeczności romskiej w Polsce w 2006 r.). Sytuacja Romów na rynku pracy w 2006 r. najgorzej przedstawiała się w województwach: kujawsko-pomorskim (100\% bezrobotnych), warmińsko-mazurskim (99,9\%) i dolnośląskim (99,5\%). Stopą bezrobocia wśród ludności romskiej powyżej 90\% charakteryzowały się również województwa: świętokrzyskie, śląskie, lubuskie i lubelskie. Województwa o najniższej stopie bezrobocia wśród tej ludności to: opolskie, mazowieckie i pomorskie (ale jedynie w województwie opolskim pracuje 2/3 Romów). Dla województw podkarpackiego i wielkopolskiego brak danych (ryc. 1). 
Z powodu tak wysokiej stopy bezrobocia aż 80\% Romów jest zależnych od państwowej sieci pomocy społecznej. Skutki tego stanu rzeczy to złe warunki życia i rosnąca przestępczość (Matulayová 2001). Permanentny brak pieniędzy sprawia, że codziennie toczą walkę o materialny byt, o zapewnienie funduszy na podstawowe potrzeby swych wielodzietnych rodzin. Problem braku wykształcenia, a co z tym związane - problem bezrobocia - jest niejako dziedziczny. Dzieci bezrobotnych rodziców, niezapewniających im środków na edukację i niepotrafiących pomóc im w nauce, podzielają los rodziców i zasilają ogromną grupę bezrobotnych.

Ryc. 1. Stopa bezrobocia wśród polskich Romów w latach 2005 i 2006

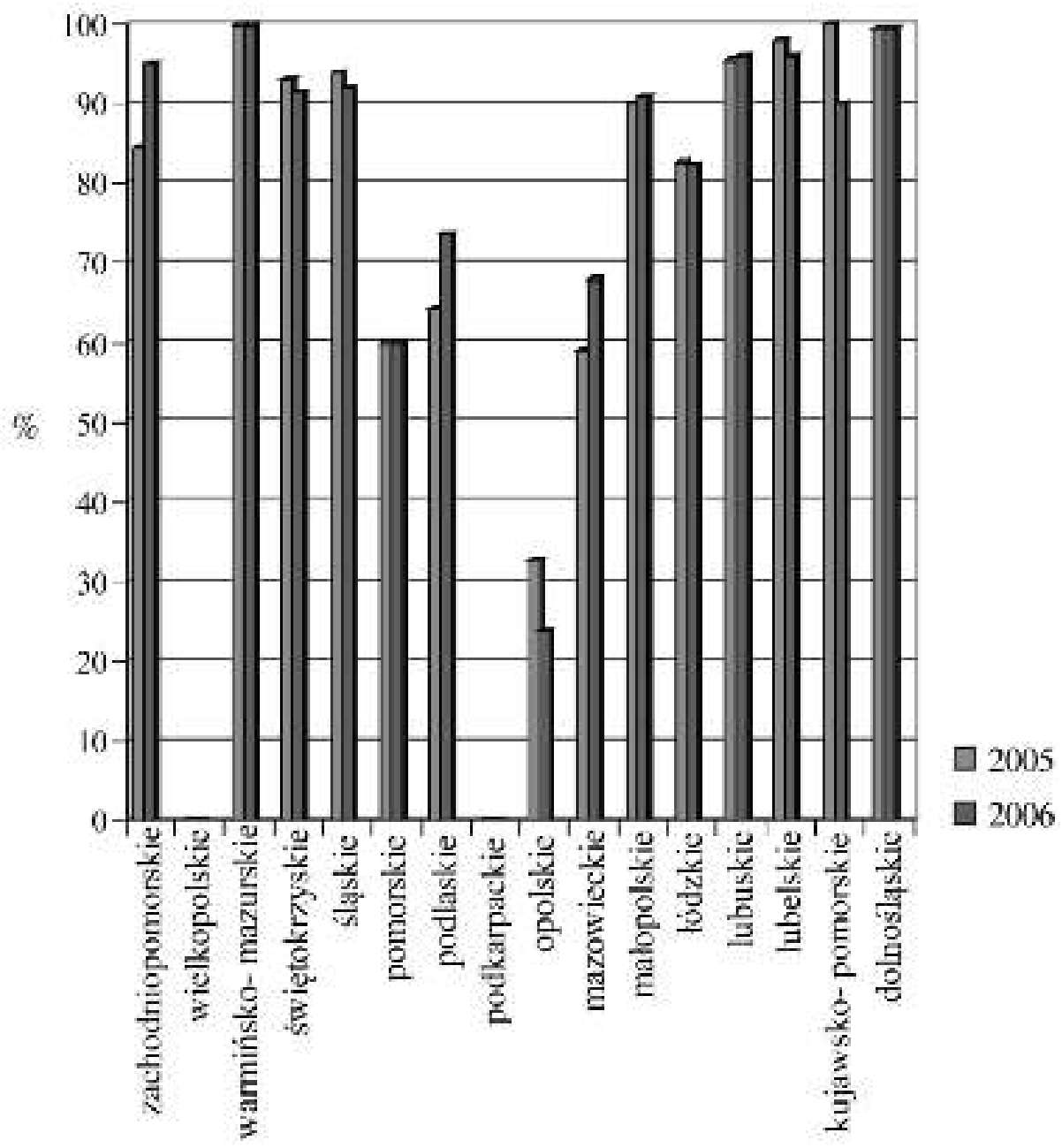

Opracowanie A. Dwojak na podstawie: Sprawozdanie z realizacji programu na rzecz społeczności romskiej w Polsce w $2006 r$.

Przykładem może być wysokie bezrobocie w rejonie Andrychowa, które powoduje, że sytuacja pod względem możliwości znalezienia zatrudnienia w tym mieście i okolicach jest wyjątkowo trudna. Romowie nie mają wykształcenia ani nawet przeszkolenia zawodowego, które jest dzisiaj niezbędne do podjęcia pracy. Większa część osób pochodzenia romskiego utrzymuje się ze świadczeń opieki społecznej, zarówno w postaci pieniężnej, jak i dofinansowania do posiłków i pomocy szkolnych dla dzieci (Zacny 2007). Inne przyczyny nieuczestniczenia Romów w rynku pracy (nie wspominając już o rozwoju przedsiębiorczości) to ich historia, tradycja i kultura.

Romowie kierują się w życiu kodeksem romanipen, który jest zbiorem zasad postępowania zgodnym z romskim wzorem kulturowym. Przekroczenie zasad romanipen grozi różnymi 
sankcjami, z których najpoważniejszą jest trwałe wykluczenie z grupy (Nowicka 2007). Zasadą nie wypływającą bezpośrednio z romanipen, ale powszechnie przyjmowaną przez większość Romów, jest przekonanie, że Rom pracuje wtedy, kiedy musi (Paszko 2007). Dla Romów praca jest czynnością nudną i mało zyskowną; preferują oni raczej działania krótkotrwałe, często jednorazowe i zyskowne (Paszko 2007).

Specyficzne podejście Romów do pracy odzwierciedlają niekonwencjonalne zajęcia, jakimi się trudnili w przeszłości. Należą do nich: muzykanctwo, kowalstwo, wyrób łyżek, wrzecion, misek z drewna, sitarstwo, grzebieniarstwo, handel końmi (nie zawsze w uczciwy sposób - znali sztuczki, dzięki którym koń w czasie sprzedaży wyglądał na młodszego i zdrowszego), kotlarstwo, niedźwiednictwo (oprowadzanie tresowanych niedźwiedzi) oraz wróżbiarstwo (Paszko 2007). Prócz wróżbiarstwa i muzykanctwa, wszystkie pozostałe tradycyjne romskie zawody dzisiaj już zanikły.

W okresie PRL-u socjalistyczna idea wymuszała na obywatelu produktywność. Uchylających się od pracy zawodowej Romów władze państwowe przymusowo asymilowały. Prowadzono szeroko zakrojoną tzw. akcję produktywizacyjno-osiedleńczą, w wyniku której większość Romów otrzymała mieszkania socjalne i pracę, zakazano im wędrowania i wprowadzono obowiązek szkolny (Sułkowska-Kądziołka 2007). Działania godzące w romską tradycję i zwyczaje, podjęte przez władze nieznające społeczności cygańskiej, spotkały się oczywiście z gwałtownym sprzeciwem mniejszości romskiej i ucieczkami. Wielu Romów udało się jednak zmusić do stałej pracy i osiadłego trybu życia. Podkreślając brutalność władz PRL-u, należy jednak przyznać, że właśnie w czasie trwania komunistycznego reżimu politycznego poziom edukacji wśród Romów był wyższy niż kiedykolwiek wcześniej, ponieważ wiele osób z tej społeczności zdobyło elementarne wykształcenie na poziomie ośmiu klas szkoły podstawowej (Kwadrans 2007). Poprawiły się także zdecydowanie warunki mieszkaniowe Romów, mieli oni bowiem wówczas stałe źródła dochodów.

Obalenie komunizmu przyniosło zdecydowane pogorszenie sytuacji społeczno-ekonomicznej Romów. W czasie grupowych redukcji stanowisk z powodu słabego wykształcenia byli w pierwszej kolejności zwalniani z pracy, a na kapitalistycznym rynku znalezienie dla nich nowego zatrudnienia było niemal niemożliwe. Wynikało to - po pierwsze $-\mathrm{z}$ braku wykształcenia, a po drugie - z negatywnego podejścia Romów do pracy.

Romowie nie mogą pozostać przy swoich tradycyjnych zajęciach, gdyż obecnie nie ma popytu na ich towary i usługi. Jedyną oprócz wróżbiarstwa tradycyjną romską profesją, która utrzymuje się na współczesnym rynku, jest handel, większość pracujących Romów handluje zatem używanymi samochodami czy ubraniami, często sprowadzanymi z zagranicy. Ułatwiają im to ich kontakty z Romami w innych krajach europejskich (Paszko, Sułkowski, Zawicki 2007). Stanowią oni jednak zdecydowanie nieliczną grupę legalnie zatrudnionych; większość pracuje nadal , na czarno" lub nie pracuje. Taka niezbyt przedsiębiorcza postawa, w połączeniu z bardzo niskim poziomem wykształcenia oraz nieumiejętnością korzystania z instrumentów wspierania przedsiębiorczości, sprawia, że ludność romska jest w Polsce grupą zagrożoną długotrwałym bezrobociem.

\section{Działania krajowych władz publicznych zmierzające do poprawy sytuacji Romów na rynku pracy}

Problemami społeczności romskiej w Polsce zajęto się w 2001 r., kiedy - pod naciskiem rządu brytyjskiego - MSWiA stworzyło i wdrożyło Pilotażowy program rzadowy na rzecz społeczności romskiej w województwie małopolskim na lata 2001-2003. Rząd brytyjski wystosował skargę do rządu polskiego, ponieważ pod koniec lat 90. XX w. znacznie wzrosła liczba emigrujących 
z Polski Romów. Program powstał przy współpracy z organizacjami romskimi, organizacjami pozarządowymi i przedstawicielami władz lokalnych, np. woj. małopolskiego. Sprawdzone w Małopolsce rozwiązania były później stosowane w wieloletnim ogólnopolskim Rządowym programie na rzecz społeczności romskiej w Polsce, wprowadzonym w 2004 r. Jego funkcjonowanie przewidziano do 2013 r., z możliwością kontynuacji. Zasadniczym założeniem programu jest zrównanie poziomu życia Romów z poziomem życia reszty polskiego społeczeństwa w dziedzinach: edukacji, zatrudnienia, zdrowia, higieny, warunków mieszkalnych oraz funkcjonowania w społeczeństwie obywatelskim (Zacny 2007). Jedne z najważniejszych elementów programu to: „rozbudzenie motywacji do zmiany kwalifikacji i podniesienia poziomu wiedzy ogólnej; objęcie bezrobotnych działaniami skłaniającymi ich do przyjęcia postawy aktywnej, przygotowanie do pracy w zawodzie poszukiwanym na rynku pracy" (Pilotażowy program rządowy na rzecz społeczności romskiej w województwie małopolskim na lata 2001-2003). Pieniądze na realizację programu, pochodzące z budżetu państwa, od kilku lat trafiają do władz lokalnych, które najlepiej powinny rozumieć problemy miejscowej ludności i wiedzieć, jak przyznane fundusze spożytkować. Odbywa się to jednak na podstawie ogólnych dyspozycji wydanych przez władze centralne. Czynnikiem warunkującym sukces działań na rzecz poprawienia sytuacji Romów w Polsce, w równej mierze co pieniądze, jest zaangażowanie przedstawicieli społeczności romskiej na każdym etapie realizowania projektu - od wstępnych planów, po aktywny udział $\mathrm{w}$ realizacji. Walka z zakorzenioną w romskiej mentalności niechęcią do pracy wymaga od realizatorów pomocy oraz spełnienia bardzo ważnego warunku - wyjątkowej konsekwencji i determinacji (Paszko, Sułkowski, Zawicki 2007).

Program, choć tak pozytywnie oceniany w Małopolsce, rozszerzony na cały kraj nie przynosi niestety zadowalających efektów. Poziom bezrobocia, pomimo prowadzenia programu od 2001 r. w Małopolsce, sięga nadal 90\%. Na negatywną ocenę działań jest jednak za wcześnie. Efekty pomocy nie mogą być natychmiastowe, gdyż barierą, oprócz braku pieniędzy, są braki edukacyjne oraz niekorzystna postawa wobec pracy, wynikająca po części z tradycji. Tych barier nie można pokonać w ciągu kilku lat; konieczna jest ciężka, konsekwentna i kosztowna praca.

Jak pokazuje doświadczenie realizatorów programu, jego dotychczasowe wyniki są bardzo różne. Urząd Miasta w Wadowicach, dzięki konsekwentnym działaniom i uzyskanym z programu pieniądzom, organizuje prace, interwencyjne i stałe. Istotne jest to, że praca nie jest przez ludność romską porzucana.

Zupełnie inne doświadczenia ma Kraków. Fundacja miasta Krakowa zorganizowała zatrudnienie grup Romów przy pracach związanych z rewitalizacją obiektów poprzemysłowych dawnego kamieniołomu Liban w Krakowie Podgórzu, a także przy tworzeniu i obsłudze na tym terenie edukacyjnych ścieżek ekologicznych oraz upamiętnieniu terenu byłego hitlerowskiego obozu zagłady w Krakowie-Płaszowie. Założeniem było, że bezrobotni Romowie dzięki pracy w fundacji uzyskają nowe kompetencje oraz doświadczenie, a także odzyskają wiarę w siebie, co pozwoli im później lepiej funkcjonować na rynku pracy, a w części przypadków będzie stanowiło podstawę do rozpoczęcia starań mających na celu założenie samodzielnej działalności gospodarczej (Paszko, Sułkowski, Zawicki 2007). Tak się jednak nie stało. Fundacja została uwikłana w spory między organizacjami romskimi, z którymi konsultowała przebieg przedsięwzięcia, i zalana roszczeniami dotyczącymi podwyższenia pensji pracownikom romskim. Kolejnym nieudanym projektem było powstanie romskiej restauracji i romskiej firmy remontowo-budowlanej w Tarnowie (Paszko, Sułkowski, Zawicki 2007). Nieudane próby nie powinny jednak powstrzymywać władz od kontynuowania działań. Z czasem, wraz z rosnącym poziomem wykształcenia ludności romskiej, projekty będą realizowane z większym powodzeniem. 
Cień nadziei twórcom programów i działaczom organizacji społecznych daje głos romskich autorytetów, którzy - jako przywódcy rodowi - dają przykład reszcie rodziny, podejmują pracę etatową lub własną działalność gospodarczą i głoszą konieczność starań o poprawienie sytuacji bytowej, poziomu edukacji i stosunków z polskim społeczeństwem. Trudności ze znalezieniem pracy mogą w przyszłości przynieść pozytywne efekty, zmuszając Romów do zakładania własnej działalności gospodarczej. Romski kodeks romanipen zdecydowanie preferuje samozatrudnienie, a nie pracę etatową (Paszko, Sułkowski, Zawicki 2007). W romskiej naturze leży dążenie do szybszego i większego zysku, a jest on zdecydowanie łatwiej osiągalny w wyniku prowadzenia własnej działalności gospodarczej. Poza tym godziny pracy są bardziej elastyczne, co jest istotne dla Romów, ceniących rodzinę i często nieobecnych w pracy, co tłumaczą ,przyczynami rodzinnymi”. Idealnym rozwiązaniem byłoby zatem zakładanie niewielkich rodzinnych firm, które przynosiłyby korzyści ekonomiczne, a nie przeszkadzały w kultywowaniu tradycyjnych romskich zwyczajów.

Oprócz działań państwowych liczne inicjatywy podejmują również instytucje prywatne, fundacje, stowarzyszenia, a nawet firmy. Ich działanie, choć bardzo cenne, jest jednak często jednorazowe, natomiast rządowy program zapewnia stały dostęp do funduszy. Wśród licznych organizacji na szczególną uwagę zasługuje Centrum Aktywizacji Zawodowej Romów. Jego celem jest zachęcenie członków społeczności romskiej do powrotu na rynek, najlepiej przez założenie własnej działalności gospodarczej, a także wspieranie istniejących romskich przedsiębiorstw (Zawicki 2007).

Ciekawym projektem aktywizacji Romów, realizowanym w Austrii, jest Mri Buti (Moja Praca) w Oberwart (Burgenland). Sam projekt nie odniósłby zakładanego sukcesu, gdyby nie wcześniejsze utworzenie Funduszu Romów oraz zmiany w szkolnictwie, w tym utworzenie ośrodka pomocy dzieciom (działającego na zasadzie świetlicy) i budowa nowoczesnego budynku domu kultury romskiej. Te zmiany były możliwe po zweryfikowaniu wielu uprzedzeń przez społeczeństwo austriackie, a także samych Romów, którzy uwierzyli, że potrafią wykorzystać proponowaną im pomoc i zasługują na nią. Kobiety zdecydowały się na pranie, szycie i prasowanie odzieży w specjalnie przeznaczonych do tego celu, nowo wybudowanych pomieszczeniach. Używana odzież, pochodząca ze zbiórek, dostarczana jest przez austriacki Caritas i inne organizacje charytatywne w Austrii, a następnie (posegregowana, wyprana w pralni, wyprasowana, ewentualnie naprawiona) sprzedawana jest niedrogo jako odzież używana w specjalnym sklepie, tzw. second hand-shop. Mężczyźni wybrali prace fizyczne w lesie, parku miejskim i ogrodach. Ich klientami są najczęściej mieszkańcy miasta Oberwart i okolicznych miejscowości. Uczestnicy projektu sami określili ramy czasu pracy i zakres swoich obowiązków. Dzięki temu przedsięwzięciu wiele rodzin romskich ma stałą pracę i wszystkie przywileje socjalne przysługujące pracownikom etatowym. Zarobki na pewno nie są atrakcyjne, ale przy tym czasie pracy, wkładzie pracy oraz rozlicznych udogodnieniach i przywilejach zasługują na uwagę. Zdecydowana większość pracowników zaangażowanych w projekcie nie podejmuje żadnej dodatkowej pracy.

Projekt Mri Buti nie jest przykładem ,,wielkiego biznesu” i górnolotnych perspektyw; jest przykładem wielkiej aktywizacji ludności biednej, niewykształconej, marginalizowanej w społeczeństwie, nie zawsze zasymilowanej, żyjącej na dalekich peryferiach (choć w bogatym kraju Unii Europejskiej). Sukcesem jest stworzenie stałych miejsc pracy dla grupy mniejszości romskiej, która w tym regionie nie może znaleźć zatrudnienia ze względu na różne bariery, w tym także dyskryminację.

Negatywnym aspektem tego przedsięwzięcia wydaje się fakt, że organizacja nowych miejsc pracy nie przełożyła się na wysoki poziom motywacji tych ludzi do większej aktywności 
zawodowej i wyzwolenia większych ambicji. Ponadto zauważa się wyraźny wzrost postaw roszczeniowych rdzennych grup mniejszości narodowych (w tym Romów) w stosunku do lokalnych władz samorządowych, a także federalnych w Wiedniu. Pracownicy opieki socjalnej i społecznej wskazują przykłady swoistej ,,przedsiębiorczości” grup mniejszości w wyszukiwaniu coraz to nowych form zasiłków i dopłat z dostępnego szerokiego pakietu spraw socjalnych (Osuch 2008).

\section{Sytuacja mniejszości romskiej w wybranych krajach Unii Europejskiej}

W Finlandii społeczny i ekonomiczny status Romów wciąż jest gorszy niż status innych Finów. Po części wynika to z uwarunkowań historycznych, ale głównymi przyczynami tej sytuacji są niższy poziom osiągnięć w nauce młodzieży romskiej i wzajemne uprzedzenia w codziennych ludzkich relacjach. W ostatnich latach uczyniono w tym kierunku znaczny postęp, ale należy jeszcze wykonać sporo pracy, by zrównać status Romów ze statusem reszty fińskiego społeczeństwa, w sferach ekonomicznej, politycznej i sferze akceptacji.

Romowie nie są adekwatnie reprezentowani w fińskim społeczeństwie na ważnych i przywódczych stanowiskach, są jednak możliwości poprawy nastawienia zarówno Romów, jak i pozostałych Finów w zakresie postrzegania siebie nawzajem jako równych sobie. Pozycja społeczna jest determinowana w dużej mierze stanem edukacyjnym. Niski poziom wykształcenia akademickiego potęguje problem bezrobocia wśród Romów w Finlandii (Trotta Tuomi, Gronfors 2007).

Poziom wykształcenia mniejszości romskiej w Rumunii jest nadal dużo niższy niż każdej innej grupy społecznej czy etnicznej w tym kraju. Pomimo licznych programów socjalnych, dających ogromną szansę poprawy sytuacji, rumuńskich Romów nadal cechują: wysoka stopa analfabetyzmu, niepowodzenia w szkole, nieuczęszczanie do szkoły lub wczesne porzucanie nauki. Przyczyny tej sytuacji to przede wszystkim: system szkolnictwa charakteryzujący się sztywną strukturą, oparty na kadrze, która nie jest szkolona z zakresu wielokulturowej edukacji, oraz bardzo restrykcyjna kultura Romów, którzy często izolują się z powodu swoich nawyków, tradycji i zwyczajów. Dzieci, z powodu braku odpowiedniego miejsca w domu, nie mają dobrych warunków do nauki. Ich pożywienie jest ubogie, co źle wpływa na zdrowie. Ubiór jest bardzo skromny, nierzadko brudny. Fakt nieposiadania ubrań i obuwia, ich zdaniem, powoduje opuszczanie zajęć w szkole.

Porzucanie szkoły jest uważane za skuteczny sposób zablokowania dostępu do dalszej nauki - ok. 45\% dzieci romskich porzuca szkołę! Wielu Romów porzuca szkołę z powodu braku środków materialnych, a tych, którzy kontynuują edukację, bardzo często spotyka dyskryminacja ze strony kolegów: są zmuszani do siedzenia w ławkach na końcu sali, traktowani z obojętnością, lub, co gorsza, czasem słownie atakowani przez uczniów i nauczycieli. Nie jest to na szczęście zjawisko powszechne, ale rozwiązanie tego problemu jest konieczne.

Brak środków materialnych, który prowadzi do opuszczania lekcji lub wczesnego porzucania szkoły, małe zainteresowanie rodziców wykształceniem dzieci, środowisko (które w niektórych szkołach jest wrogo ustosunkowane do Romów) - to tylko niektóre problemy romskich dzieci. Wczesne zawieranie małżeństw przez dziewczęta, pomimo obowiązku nauki, jest jednym z głównych powodów porzucania przez nie szkoły. Wszystkie te niesprzyjające warunki, w połączeniu z codziennym, trudnym życiem romskich dzieci, mają negatywny wpływ na edukację, stosunki społeczne, a także na ich tożsamość.

Dla Romów wyższe wykształcenie powinno być bardzo ważnym czynnikiem edukacji w przyszłości, toteż młodzi ludzie należący do romskiej mniejszości byli zachęcani do wstępowania na wyższe uczelnie. W ostatnich latach bardzo powoli, ale systematycznie wzrasta liczba romskich studentów na Uniwersytecie w Bukareszcie (Nichersu, Porumcia 2007). 


\section{Ekonomiczne instrumenty wspierania romskiej społeczności na rynku pracy}

Nieprzystosowanie wielu Romów do współczesnego rynku pracy wyraża się również nieumiejętnością korzystania z pomocy powszechnie dostępnej wszystkim drobnym przedsiębiorcom w Polsce. Przykładowo, w połowie lat 90. XX w. kilkunastu krakowskich Romów zaciągnęło preferencyjne pożyczki dla osób bezrobotnych pragnących podjąć działalność gospodarczą na własną rękę. W prowadzeniu własnej działalności Romowie upatrywali swej szansy na osiągnięcie natychmiastowego, dużego zysku. Za pożyczone pieniądze planowali stworzyć firmy handlowe i remontowo-budowlane. Jednak w ciągu trzech lat większość tych, którzy wzięli pożyczki, znów była oficjalnie bezrobotna. Niektórzy wykorzystali pieniądze na bieżącą konsumpcję, inni po dwóch, trzech latach zrezygnowali z prowadzenia legalnej działalności gospodarczej i przenieśli się na „czarny rynek”, by zwiększyć zyski (Paszko, Sułkowski, Zawicki 2007).

Konieczne zatem wydaje się wcześniejsze organizowanie szkoleń, przekwalifikowanie, prowadzenie doradztwa zawodowego oraz organizowanie pracy subsydiowanej (Pilotażowy program rzadowy...). Dopiero po powrocie Romów na rynek pracy, dokształceniu ich i zapoznaniu z podstawowymi zasadami prowadzenia własnej firmy można udzielać im dalszej pomocy w celu rozwoju ich przedsiębiorczości.

Według Paszko, Sułkowskiego i Zawickiego (2007), najlepszymi środkami wsparcia przedsiębiorczości mniejszości narodowych i etnicznych są instrumenty mikrofinansowe oraz sprawiedliwy handel. Do instrumentów mikrofinansowych zalicza się: pożyczki, ubezpieczenia, wkłady oszczędnościowe, usługi transferowe i inne usługi finansowe. Są to również kredyty i tzw. mikrokredyty (kredyty o niewielkiej wartości pieniężnej, udzielane często bez zabezpieczeń). Małe kredyty umożliwiają założenie własnej firmy i poczynienie w niej pierwszych inwestycji w czasie początkowego, najtrudniejszego okresu działalności. Mogą to być kredyty zaciągane przez kilka osób, co jest dodatkowym atutem dla romskiej społeczności charakteryzującej się kohezją grupową. Zaciągając wspólnie kredyt, Romowie mogą się wzajemnie motywować do jego spłaty.

Drugim zaproponowanym przez autorów instrumentem ekonomicznym, który w skuteczny sposób mógłby wspierać rozwój postawy przedsiębiorczej wśród polskich Romów, jest „sprawiedliwy handel” (Paszko, Sułkowski, Zawicki, 2007). „Sprawiedliwy handel” jest ideą istniejącą od ponad 40 lat. Polega on na podejmowaniu przez różne organizacje działań zmierzających do sprawiedliwego podziału zysków ze sprzedaży towarów na świecie. Ma on na celu obronę drobnych wytwórców z krajów „biednego Południa” przed wielkimi przedsiębiorstwami i organizacjami zarabiającymi na pośrednictwie. Głównym celem jest doprowadzenie do tego, by wytwórca otrzymywał godziwą pensję za swoją pracę, która pozwoli mu na utrzymanie siebie i rodziny. Cel ten osiąga się przez wspieranie producentów i podnoszenie świadomości bogatych konsumentów (Zięba 2004).

Idea walki z niesprawiedliwością na rynku światowym może zostać przystosowana do warunków polskich. Grupą chronioną będą Romowie, zajmujący się tradycyjną wytwórczością. Jest to kolejny pomysł pomocy Romom i ich aktywizacji na rynku pracy, a w perspektywie - także rozwoju romskiej przedsiębiorczości.

\section{Podsumowanie}

Działania na rzecz społeczności romskiej podejmowane w Polsce w ostatnich latach są przykładem prawidłowego reagowania władz państwowych na długotrwały stan bezradności tej grupy etnicznej wobec aktualnej sytuacji ekonomicznej. Doświadczenia kilku lat programu w Polsce, a także przywołanych przykładów działań zagranicznych pokazują, że udzielanie Romom pomocy nie jest łatwe, gdyż jej podstawą jest wypracowanie pozytywnego stosunku 
do pracy, a w dalszej kolejności zaszczepienie ducha przedsiębiorczości. Samo przekazanie funduszów sprawy nie rozwiązuje. Sytuację utrudniają zasady romskiej kultury i tradycji oraz wzajemne polsko-romskie uprzedzenia. Pozostaje jedynie liczyć na kontynuację pomocy państwa i na to, że z czasem sytuacja Romów w Polsce poprawi się na tyle, iż będą oni w stanie być samodzielną i przedsiębiorczą częścią polskiego społeczeństwa.

\section{Literatura}

1. Aktywizacja zawodowa Romów, 2007, M. Zawicki (red.), Małopolska Szkoła Administracji Publicznej Akademii Ekonomicznej w Krakowie, Kraków, s. 47-51.

2. Fridrich Ch., 2007, Romowie w Austrii - znikomo zintegrowani, ale marginalizowani albo asymilowani [w:] Wybrane problemy edukacyjne i kulturowe niektórych mniejszości narodowych i etnicznych w Polsce i Europie, W. Osuch (red.), Geoinfo Kraków, s. 55-63.

3. Kwadrans Ł., 2007, Charakterystyka sytuacji edukacyjnej Romów w Czechach, Polsce i Stowacji po 1989 roku [w:] Romowie w Polsce i Europie, P. Borek (red.), Wydawnictwo Naukowe Akademii Pedagogicznej, Kraków, s. 233-248.

4. Matulayová T., 2001, Praca socjalna w środowisku Romów [w:] Oświata etniczna w Europie Środkowej, Z. Jasiński, T. Lewowicki (red.), Wydawnictwo Uniwersytetu Opolskiego, Opole, s. 335-338.

5. Nichersu J., Porumcia A., 2007, Romska mniejszość narodowa w Rumunii $i$ Wschodniej Rumunii [w:] Wybrane problemy edukacyjne i kulturowe niektórych mniejszości narodowych i etnicznych w Polsce i Europie, W. Osuch (red.), Geoinfo Kraków, s.74-80.

6. Nowicka E., 2007, Romowie i świat współczesny [w:] Romowie w Polsce i Europie, P. Borek (red.), Wydawnictwo Naukowe Akademii Pedagogicznej, Kraków, s. 124-147.

7. Osuch W., 2008, Problem aktywizacji spolecznej $i$ zawodowej romskiej mniejszości narodowej w Austrii na przykładzie miasta Oberwart [w:] Przedsiębiorczość - Edukacja nr 4, Z. Zioło, T. Rachwał (red.), Wydawnictwo Nowa Era Sp. z o.o., Warszawa-Kraków 2008.

8. Paszko A., 2007, Romowie i polskie doświadczenie wolnego rynku [w:] Romowie w Polsce i Europie, P. Borek (red.), Wydawnictwo Naukowe Akademii Pedagogicznej, Kraków, s. 204-216.

9. Romowie na rynku pracy, 2007, A. Paszko, R. Sułkowski, M. Zawicki (red.), Małopolska Szkoła Administracji Publicznej Akademii Ekonomicznej w Krakowie, Kraków.

10. Sułkowska-Kądziołka A., 2007, Wybrane programy edukacyjne dla mniejszości romskiej w Małopolsce [w:] Romowie w Polsce i Europie, P. Borek (red.), Wydawnictwo Naukowe Akademii Pedagogicznej, Kraków, s. 263-265.

11. Toborowicz I., 2008, Społeczeństwo informacyjne, artykuł zamieszczony na portalu internetowym Global Economy: http://globaleconomy.pl/content/view/145/17/ (30.06.2009 r.).

12. Trotta Tuomi M., Gronfors J., 2007, Mniejszość romska w Finlandii - przeglad [w:] Wybrane problemy edukacyjne i kulturowe niektórych mniejszości narodowych i etnicznych w Polsce i Europie, W. Osuch (red.), Geoinfo Kraków, s. 51-54.

13. Zięba W., 2004, Sprawiedliwy handel - gra fair [w:] „Magazyn Obywatel”, 1/2004 (15), Stowarzyszenie Obywatele Obywatelom, Łódź.

\section{Strony internetowe Ministerstwa Spraw Wewnętrznych i Administracji}

1. Mniejszości narodowe i etniczne w Polsce. Podstawowe prawa, http://www.mswia.gov.pl/ portal/pl/61/38/Podstawowe_prawa.html

2. Sprawozdanie z realizacji programu na rzecz społeczności romskiej $w$ Polsce $w 2006$ r., http://www.mswia.gov.pl/portal/pl/184/4953/Sprawozdanie_z_realizacji_Programu_na_rzecz_spolecznosci_romskiej_w_Polsce_w_200.html

3. Pilotażowy program rządowy na rzecz społeczności romskiej w województwie matopolskim na lata 2001-2003, http://www.mswia.gov.pl/portal/pl/192/285/Tresc_pilotazowego_programu_rzadowego_ na_rzecz_spolecznosci_romskiej_w_wojewodzt.html 


\section{Supporting Entrepreneurship by Acting against Social and Economic Exclusions of Groups Misfit in the Market Economy Competition as a Pursuing to Balanced Growth of the Information Society (on the Example of Roma Minority)}

The article refers to social and economic issues of Roma minority in Poland. Large groups of Roma that live in our country - especially in the cities - are marginalized because of their culture dissimilarity and because they cannot find their place in actual political and economic situation. The reason, but also the effect, of such situation is explained by low level of education in Poland. Authors reckon that one of the conditions of information society's growth is necessity to support their enterprising attitudes. Following this thesis, the authors believe, that supporting lower developed groups, which don't keep up with actual pace of economic growth, is necessary to minimize the social and economic exclusion of these groups and to limit social anxieties and clashes.

On the example of Roma ethic minority group authors characterized the problems of these groups on a labor market, ways of fighting against them and showed the perspectives of progress of these groups in future by building enterprising attitudes. 